\title{
ROLE OF VARIOUS SURGICAL OPERATIONS IN THE HISTORY OF PATIENTS WITH RHEUMATOID ARTHRITIS
}

\author{
BY \\ LENNART KALLIOMÄKI \\ Medical Clinic of the University, Turku, Finland
}

(RECEIVED FOR PUBLICATION JULY 5, 1954)

\begin{abstract}
Although the aetiology of rheumatoid arthritis still remains unexplained, it is known that a number of external circumstances of various kinds may be at least the apparent precipitating factor. Among such factors may be mentioned infections, traumata, confinements, etc.
\end{abstract}

The investigation by Edström (1951) on the correlation of trauma and rheumatoid arthritis is based on a study of 2,034 patients, in 72 of whom (3.5 per cent.) the onset of the disease occurred immediately following a trauma. The ratio between females and males was 15:57 among these 72 patients, whereas it was $66: 33$ in the total series. From this observation in particular Edström drew the conclusion that the development of the disease is not merely a chance occurrence and that trauma also plays an aetiological role. In studying the part possibly played by pregnancy and parturition, Oka (1953) based his observations on 732 female patients over 15 years of age, and arrived at the conclusion that the onset of rheumatoid arthritis during pregnancy or immediately thereafter is so common that under certain circumstances pregnancy and parturition can be considered as aetiological factors.

It was the object of the present study to examine the role of certain of the more common surgical operations in the history of patients with rheumatoid arthritis.

\section{Material}

The series comprised 187 female patients over 20 years of age, who underwent treatment for rheumatoid arthritis in the Turku Polyclinic for Rheumatic Diseases. Female cases only were included in this study in order that the material would be uniform in its relation to all the types of operation studied.

\section{Results}

The results of the inquiry are shown in the Table. Amputative gynaecological operations and thyroidectomies were the most prominent operations in the previous history of these patients. The ratio of thyroidectomies to appendicectomies and tonsillectomies in this series does not conform with the normal ratio, since, for instance, the Surgical Clinic of the Turku University performs yearly about 600 appendicectomies but only 100-150 thyroidectomies. The thyroidectomized group, furthermore, includes two patients in whom the operation could be considered to have had a definite aetiological role in rheumatoid arthritis, and two patients in whom the operation caused an exacerbation of this disease.

$$
\text { TABLE }
$$

INCIDENCE OF SURGICAL OPERATIONS IN 187 FEMALE PATIENTS WITH RHEUMATOID ARTHRITIS

\begin{tabular}{|c|c|c|c|c|c|}
\hline \multirow{3}{*}{ Operation } & \multirow{2}{*}{\multicolumn{2}{|c|}{ Patients }} & \multicolumn{3}{|c|}{ Time of Operation } \\
\hline & & & \multirow{2}{*}{$\begin{array}{l}\text { Before } \\
\text { Onset }\end{array}$} & \multicolumn{2}{|c|}{ After Onset } \\
\hline & No. & $\begin{array}{l}\text { Per } \\
\text { cent. }\end{array}$ & & $\begin{array}{c}\text { No } \\
\text { Influence }\end{array}$ & $\begin{array}{l}\text { Exacer- } \\
\text { bation }\end{array}$ \\
\hline $\begin{array}{l}\text { Uterus amputation } \\
\text { Oophorectomy }\end{array}$ & $\left.\begin{array}{l}8 \\
2\end{array}\right\}$ & $5 \cdot 3$ & $\begin{array}{l}5 \\
2\end{array}$ & 3 & \\
\hline Thyroidectomy & 10 & $5 \cdot 3$ & 8 & & 2 \\
\hline Tonsillectomy & 9 & $4 \cdot 8$ & 6 & 2 & 1 \\
\hline Appendicectomy .. & 5 & $2 \cdot 1$ & 5 & & \\
\hline Cholecystectomy .. & 3 & $1 \cdot 6$ & 2 & 1 & \\
\hline
\end{tabular}

\section{Case Reports}

Case 1, the 49-year-old wife of a policeman, underwent thyroidectomy in November, 1952. There had been symptoms of thyrotoxicosis for about 6 months previously. One month after the operation she began to feel tenderness in all joints and a typical case of rheumatoid arthritis developed.

Case 2, a housemaid aged 43, underwent thyroidectomy in 1938. In 1939 there was an onset of rather severe typical rheumatoid arthritis, which resisted all therapeutic measures. Symptoms of hypothyreosis began to appear at about the same time. 
Case 3, shop assistant aged 56, developed typical rheumatoid arthritis in 1952. On her admission for treatment on July 15, 1953, active rheumatoid arthritis and also a large nodular goitre and obvious thyrotoxicosis were diagnosed. Gold therapy was immediately instituted but the patient reacted poorly. From September 12 to December 11, 1953, she received treatment at the hospital of the Rheumatic Diseases Foundation in Heinola. On discharge the joint processes were fairly quiet. However, as the symptoms of thyrotoxicosis became increasingly evident and cardiac insufficiency began to develop, thyroidectomy was indicated. The operation was performed in March, 1954, after which the heart and general physical condition improved, and her weight increased. One month later, however, a definite exacerbation of the rheumatoid arthritis occurred, and the erythrocyte sedimentation rate rose to 45-91 mm./hr. The patient had previously tolerated gold without any complications, but now even small doses $(0.01 \mathrm{~g}$.) produced leukopenia.

Case 4, a 34-year-old dressmaker, reported the onset of rheumatoid arthritis 7 years previously, and 3 years after that a pregnancy, during which all the joint symptoms disappeared. Thyroidectomy was performed in January, 1954, because of mild thyrotoxicosis, and 3 weeks after the operation there was a sudden onset of very active rheumatoid arthritis, and typical symptoms of hypothyreosis appeared simultaneously.

No time correlation could be seen between the other surgical operations and the onset of rheumatoid arthritis in these four patients.

In order to study the incidence of uterus amputations, oophorectomies, and thyroidectomies in a control series of patients not affected by rheumatoid arthritis I collected from the Medical Clinic of the Turku University a series of 150 female patients over 20 years of age who were hospitalized for various infectious diseases, hypertension, and degenerative heart disease. The gynaecological operations mentioned had been previously performed in eight $(5 \cdot 3$ per cent.) and thyroidectomy in three ( 2 per cent.). The history of the rheumatoid arthritis and control series was thus similar as regards gynaecological operations, but thyroidectomy was more frequent in the history of the rheumatoid arthritis patients. The difference is not statistically significant (difference $3 \cdot 3 \pm 1 \cdot 9$ ), though the opinion that thyroidectomy may influence the onset or exacerbation of rheumatoid arthritis is borne out by the four cases described above.

It seems probable that the thyroid also affects the development of rheumatoid arthritis in other ways. Experimental studies (Selye and others, 1944; Harrison and Barnett, 1953) and clinical investigations (Stepantschitz and Schreiner, 1952) are in favour of this opinion. In weighing the indications for thyroidectomy in a patient with rheumatoid arthritis, consideration should be given to the possible aggravating effect of the operation on the course $\overline{\overline{3}}$ of the joint disease. Before a diagnosis of thyro- $\square$ toxicosis is made in a patient with rheumatoid arthritis it should be remembered that the latter $\overrightarrow{\vec{F}}$ disease may simulate the symptoms of thyro- $\frac{\overrightarrow{0}}{0}$ toxicosis (tachycardia, sweating, psychic lability, $\frac{\bar{\sigma}}{\mathrm{O}}$ etc.). It is obvious, of course, that if a definite $\overline{\bar{\sigma}}$ diagnosis of thyrotoxicosis is made in an arthritic patient, the thyroid disease must be treated first, since thyrotoxicosis is a graver condition prog- $\infty$ nostically than rheumatoid arthritis.

\section{Summary}

(1) A study was made of the role of certain surgical operations in the history of 187 female patients with rheumatoid arthritis.

(2) Uterus amputation and oophorectomy had $\vec{\omega}$ been performed in $5 \cdot 3$ per cent. of these cases, and $\omega$ the incidence was the same in a control series. $\rightarrow$ Thyroidectomy had been performed in 5.3 per cent. 을 of the rheumatoid arthritis patients and in only 2 per cent. of the control cases (difference $3 \cdot 3 \pm 1 \cdot 9$ ). Other studied operations noted were appendicectomy in $2 \cdot 1$ per cent., tonsillectomy in $4 \cdot 8$ per cent., and cholecystectomy $1 \cdot 6$ per cent.

(3) In two cases of previous thyroidectomy $2 \overrightarrow{\overrightarrow{0}}$ definite correlation was evident between the surgic क्तु of operation and the onset of rheumatoid arthritis. In two other cases exacerbation of the joint diseas immediately following thyroidectomy was clearly demonstrable. No time correlation was seen $\bar{\partial}$ between the other operations studied and the onset or course of rheumatoid arthritis.

(4) It is pointed out that thyroidectomy should be $\overrightarrow{\overrightarrow{0}}$ performed on patients with rheumatoid arthritis $\frac{0}{3}$ only when there are grave indications for the operation.

\section{REFERENCES}

Edström, G. (1951). Rev. Rhum., 18, 507.
Harrison, R. G., and Barnett, T. J. (1953). Annals of the Rheumatic Diseases, 12 , 275 .

Oka, M. (1953). Ibid., $12,227$.

Selye, H., Sylvester, Ö., Hall, C. E., and Leblond, C. P. (1944). J. Amer. med. Ass., 124, 201

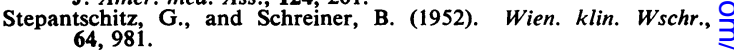

Role de différentes opérations chirurgicales dans l'histoire des malades atteintes d'arthrite rhumatismale RÉSUMÉ

(1) On étudia le rôle de certaines opérations chirur- $\widetilde{N}$ gicales dans l'histoire de 187 malades atteintes d'arthrite ? rhumatismale.

(2) L'hystérectomie et l'oophorectomie fut effectuée dans 5,3 pour cent des cas; le pourcentage de ces opéra- $\omega$ tions chez les témoins fut similaire. La thyroïdectomie fut effectuée dans 5,3 pour cent des cas d'arthrite rhumatismale et chez 2 pour cent seulement des témoins (différence $3,3 \pm 1,9$ ). D'autres opérations notées furent: appendicectomie chez 2,1 pour cent, amygdalectomie? chez 4,8 pour cent et cholecystectomie chez 1,6 pour cent. $\square$ 
(3) Dans deux cas de thyroïdectomie antérieure un rapport défini entre l'opération et le début de l'arthrite rhumatismale fut évident. Dans deux autres cas l'exacerbation de la maladie articulaire immédiatement après la thyroïdectomie fut clairement démontrable. On n'observa pas de rapport de temps entre les autres opérations étudiées et le début ou l'évolution de l'arthrite rhumatismale.

(4) On fait remarquer que la thyroildectomie n'est indiquée chez les rhumatisants que pour des raisons graves.

El papel de varias operaciones quirúrgicas en la historia de enfermas con artritis reumatoide

\section{Sumario}

(1) Se estudió el papel de algunas operaciones quirúrgicas en la historia de 187 enfermas con artritis reumatoide.
(2) La histerectomía y la ooforectomía fueron efectuadas en el 5,3 por ciento de los casos, con el número similar de tales operaciones en los testigos. El 5,3 por ciento de las enfermas reumáticas y tan sólo un 2 por ciento de los testigos (diferencia $3,3 \pm 1,9$ ) fueron tiroidectomizadas. Otras operaciones notadas fueron: apendicectomia 2,1 por ciento, amigdalotomía 4,8 por ciento y colecistectomía 1,6 por ciento.

(3) En dos casos de tiroidectomía anterior una relación determinada entre la operación y el comienzo de la artritis reumatoide fué evidente. En dos otros casos la exacerbación de la enfermedad articular inmediatamente después de la tiroidectomía fué claramente demostrable. No se observó relación alguna de tiempo entre las demás operaciones estudiadas y el comienzo o la evolución de la artritis reumatoide.

(3) Se hace observar que la tiroidectomía en enfermos con artritis reumatoide se debe efectuar tan sólo en caso de indicación grave. 